\title{
Konstruksi Prinsip Kinerja Public Relations Dalam Pandangan Syariat Islam
}

\author{
Mubarok dan Dian Marhaeni K \\ (mubarok@unissula.ac.id) \\ (Fakultas Ilmu Komunikasi, Universitas Sultan Agung)
}

\begin{abstract}
$P R$ performance principle formulated as part of the management functions to achieve the objectives of an organization. Likewise with the influence of religious scriptures embraced by every individual involved in the communication process. One scripture that the reference human life is the Qur'an as a way of life of Muslims. Related to the practice and science of public relations it is interesting to look at dikontruksi how Islamic law principle of PR performance. The scales of the Shari'a as an integral part of the life of a Muslim will guide how he practice the principles of PR performance. Institutions are trying to get support through activities that can provoke support from the public without coercion or through a stage of conflict. Arthur W. Page mentions a number of principles that can be used in practice and as a philosophical PR in maintaining relations with the public institutions.
\end{abstract}

Keywords: Public Relations, Performance, Islam

\section{Pendahuluan}

Public relations adalah fungsi manajemen yang diharapkan menjadi koalisi dominan dalam struktur organisasi.Prinsip kinerja PR dirumuskan sebagai bagian dari fungsi manajemen untuk mencapai tujuan dari suatu organisasi.Definisi tentang PR yang dikemukakan oleh para ilmuwan menekankan dari berbagai sudut pandang dan posisi yang berbeda dalam sebuah struktur organisasi. Beberapa definisi dari PR hanya menekankan pada aspek kerja, sebagian yang lain menekankan pada peran dan fungsi sementara posisi dalam struktur manajemen menandai peran penting PR dalam organisasi.

Berikut beberapa definisi dari PR.

Definisi public relations adalah usaha yang direncanakan secara terus-menerus dengan sengaja, guna membangun dan mempertahankan pengertian timbal balik antara organisasi dan masyarakatnya. Pendapat ini menunjukkan bahwa public relations dianggap sebuah proses atau aktivitas yang bertujuan untuk menjalin komunikasiantara organisasi dan pihak luar organisasi. Pengertian public relations adalah: Interaksi dan menciptakan opini publik sebagai input yang menguntungkan untuk kedua belah pihak, dan merupakan profesi yang profesional dalam bidangnya karena merupakan faktor yang sangat penting dalam pencapaian tujuan organisasi dengan secara tepat dan dengan secara terus menerus karena public relations merupakan kelangsungan hidup organisasi yang bersangkutan.

Hal ini didukung oleh pendapat yang mengatakan bahwa "public relations adalah kegiatan komunikasi yang dimaksudkan untuk membangun citra yang baik terhadap perusahaan". Sedangkan ada yang mengatakan "public relations adalah suatu perencanaan dengan menggunakan komunikasi persuasif untuk mempengaruhi persepsi masyarakat" (Utari, 2012: 12). Selain itu, "public relations adalah suatu perencanaan yang mendorong untuk mempengaruhi persepsi masyarakat melalui pelaksanaan tanggung jawab sosial 
berdasarkan suatu komunikasi timbal balik untuk mencapai keuntungan pada kedua belah pihak".

Beberapa definisi yang telah diungkapkan menekankan pada beberapa hal pokok yaitu: interaksi, hubungan antar lembaga, komunikasi persuasif, perencanaan dan proses komunikasi. Dari definisi yang telah diungkapkan oleh para ahli tersebut dapat ditarik pengertian secara umum dan khusus.

Secara keseluruhan tujuan dari public relations adalah untuk menciptakan citra baik perusahaan sehingga dapat menghasilkan kesetiaan publik terhadap produk yang ditawarkan oleh perusahaan. Selain itu public relations bertujuan untuk menciptakan, membina dan memelihara sikap budi yang menyenangkan bagi lembaga atau organisasi di satu pihak dan dengan publik di lain pihak dengan komunikasi yang harmonis dan timbal balik.

Sumber perkembangan teori komunikasi terbuka luas dari beragam disiplin ilmu termasuk di dalamnya kajian dari kitab suci agama dan kearifan pemikiran lokal yang ada di setiap suku bangsa.Teori komunikasi sebagai bahan kajian dan implementasi teori dalam praksis tidak terlepas dari pengaruh kearifan lokal yang ada di setiap suku bangsa. Demikian halnya dengan pengaruh kitab suci agama yang dianut oleh setiap individu yang terlibat dalam proses komunikasi. Kitab suci agama adalah sumber pedoman bertingkah dan berperilaku dalam kehidupan sehari-hari.Tata nilai yang terkandung dalam kitab suci sarat dengan nilai-nilai moral dan spiritual yang menjadi pembeda dalam rujukan keilmuan. Salah satu kitab suci yang menjadi acuan kehidupan manusia adalah AL Qur'an sebagai pedoman hidup umat Islam.Islam adalah agama samawi yang dianut oleh jutaan manusia di dunia.Penyebaran umat Islam di dunia dengan sendirinya merepresentasikan penyebaran implementasi nilai-nilai AL Qur'an dalam kehidupan manusia di berbagai penjuru dunia. Nilai-nilai tersebut menjadi pedoman dalam bertingkahlaku di semua aspek kehidupan manusia. Kegiatan berkomunikasi yang dilakukan oleh umat Islam dengan sendirinya juga tidak lepas dari tuntunan yang ada dalam kitab suci tersebut.

Al Qur'an adalah kitab suci yang terjaga keotentikannya sehingga isi yang terkandung di dalamnya sama dari awal diturunkannya. Al Qur'an turun kepada Rasulullah Muhammad SAW semenjak empat belas abad yang lampau dan sampai hari ini tetap terjaga keotentikannya. Jaminan akan otentisitas tersebut berasal dari Alloh SWT yang berfirman: "Sesungguhnya Kami yang telah menurunkan AL Qur'an dan sesungguhnya Kami pula yang akan menjaganya (Q.S Al Hijr:15)"

Kandungan AL Qur'an secara garis besar terbagi dalam tiga hal:

1. Akidah

Aqidah adalah ilmu yang mengajarkan manusia mengenai kepercayaan yang wajib dimiliki oleh seorang muslim.

\section{Ibadah}

Ibadah adalah taat, tunduk, terhadap syariat ibadah yang telah ditentukan dalam syariat Islam.Dalam pandangan para ahli fikih, ibadah didefinisikan sebagai segala bentuk ketaatan yang dijalankan untuk mendapatkan ridho Alloh SWT.

3. Muamalah

Muamalah mengatur hubungan antarmanusia dalam beberapa ikatan seperti ekonomi, perdagangan, akhlak, dan hubungan lain yang bersifat perseorangan dan kelompok.

4. Sejarah/kisah-kisah 
Sejarah dari umat-umat terdahulu diceritakan dalam Al Qur'an untuk memberikan pelajaran bagi manusia.Beragam kisah tersebut merupakan pedoman berbuat dan berperilaku bagi umat yang mau mengambil pelajaran.

5. Hukum

Hukum dalam Al Qur'an mengatur segala aspek terkait hubungan manusia dengan Rab, manusia dengan sesamanya, dengan lingkungan, binatang yang terkait dengan aspek hukum.

Isi Al Qur'an yang menjadi pedoman bagi jutaan umat di seluruh dunia merupakan sumber dari beragam ilmu pengetahuan manusia.Ilmu komunikasi sebagai salah satu cabang ilmu yang berkembang dengan beragam sumber juga tidak lepas dari pembahasan dalam AL Qur'an.Kitab yang bersumber dari wahyu ilahi merupakan kesempurnaan yang dijamin dan terjaga dari waktu ke waktu.

Terkait praktek dan keilmuan public relations maka menarik untuk dikontruksi bagaimana syariat Islam memandang prinsip kinerja PR. Timbangan dari syariat sebagai bagian tak terpisahkan dari kehidupan seorang muslim akan memandu bagaimana dia mempraktekan prinsip kinerja PR.

Sementara itu, Arthur W. Page menyebutkan sejumlah prinsip yang dapat digunakan dalam praktek dan sebagai filosofis PR dalam menjaga hubungan lembaga dengan publiknya. Prinsip tersebut meliputi: Tell the Truth, Prove it with Action, Listen to The Customer, Manage for Tomorrow, Conduct Public Relationss as If The Whole Company Depends On it, Remain Calm, Patient and Good Humored. Prinsip-prinsip kinerja tersebut dibuat dalam sudut pandang ilmuan barat dan bukan tradisi keilmuan Islam. Karena itu pada penelitian ini akan dilihat bagaimana konstruksi syariat Islam dalam memandang pinsipprinsip kinerja public relations tersebut. Hal ini penting mengingat praktek public relations telah menjadi bagian tidak terpisahkan dari instansi, perusahaan maupun individu umat Islam.

Karena itu menarik untuk mengetahui bagaimana konstruksi syariat Islam dalam memandang prinsip-prinsip kinerja public relations menurut Arthur W. Page yang meliputi prinsip: Tell the Truth, Prove it with Action, Listen to The Customer, Manage for Tomorrow, Conduct Public Relationss as If The Whole Company Depends On it, Remain Calm, Patient and Good Humored.

\section{Metodologi Penelitian}

Penelitian ini menggunakan pendekatan kualitatif yaitu penelitian yang hasilnya tidak diwujudkan dalam perhitungan angka melainkan di deskripsikan dalam tulisan. Menurut Moleong (2008: 5) penelitian kualitatif merupakan penelitian yang memanfaatkan wawancara terbuka untuk menelaah dan memahami sikap, pandangan, perasaan dan perilaku individu atau kelompok orang.Metode penelitian yang digunakan adalah metode kualitatif dengan deskriptif analisis.

Penelitian kualitatif sangat sering digunakan pada ilmu sosial yang lebih dulu lahir seperti pada Antropologi yang dikenal dengan tradisi ethnography, Sosiologi dengan tradisi observasi partisipasi, dan Psikologinalisis dengan tradisi life history.Karena itu, munculnya penelitian kualitatif sangat erat kaitannya dengan sifat unik dari realitas sosial yang terwujud pada tingkah laku manusia itu sendiri. Artinya, setiap realitas sosial sangat kontekstual. 
Fenomena sosial yang unik sebagai konsekuensi dari hakekat manusia sebagai makhluk psikis, sosial, dan budaya yang unik pula. Oleh karena itu, manusia tidak lepas dari makna dan interpretasi dalam membetuk sikap yang pada akhirnya memunculkan tingkah laku. Selain itu, makna dan interpretasi itu sendiri terkonstruksi pada diri setiap manusia sebagai aktor sosial melalui proses social (komunikasi) dalam suatu lingkungan sosial dan budaya unik dan dinamis (Emrus, 2012: 354-355).

1. Objek penelitian

Prinsip kerja public relations menurut Arthur W. Page yang dikonstruksi dari sudut pandang syariat Islam yang bersumber dari Tafsir Al Qur'an dan Hadits Nabi.

2. Teknik pengumpulan data

a. Wawancara

Wawancara dilakukan dengan narasumber ilmuan dan praktisi PR, dan para ulama yang menguasai syariat.

b. Studi pustaka

Studi Tafsir Al Qur'an, Hadits, dan buku teks public relations. Sumber lain yang relevan untuk menunjang analisa dan pengembangan pembahasan.

3. Analisis data

a. Data hasil wawancara akan disimpulkan dan diberikan penafsiran yang terkait dengan teori komunikasi

b. Data hasil studi literatur akan dikombinasikan dengan literatur komunikasi untuk mengahsilkan pembahasa yang lebih komprehensif

c. Data hasil wawancara dan studi literatur akan digabungkan sehingga mengahsilkan sebuah konstruksi terori komunikasi berdasar pada hasil penelitian

\section{Hasil dan Pembahasan}

Uraian pertama tentang pemahaman Public Relations, bahwa
Public Relations is the management function that establishes and maintains mutually beneficial relationships between an organization and the publics on whom success or failure depends. Public relations adalah fungsi manajemen yang membangun dan menjaga hubungan yang saling menguntungkan antara organisasi dengan publiknya dimana kesuksesan dan kegagalan hubungan itu tergantung pada Public relations tersebut.

Dalam Islam Allah menyuruh manusia untuk bergabung dalam organisasi dan bekerjasama dengan manusia lain.

Allah berfirman :"Sesungguhnya Allah menyukai orang-orang yang berperang (berjuang) dijalannya dengan terorganisasi rapih, seperti sebuah bangunan yang tersusun kuat". (QS. asShaf: 4)

Definisi Public Relations dari Cutlip juga mengandung pengertian tentang kedudukan sebagai fungsi manajemen atau memiliki kedudukan yang dekat dengan pimpinan karena harus ikut serta dalam proses pengambilan keputusan. Bagaimana kedudukan manusia atau kelompok manusia dalam Islam. Islam menganggap sama kedudukan manusia dari tujuan manusia diciptakan. Seperti dalam firman Allah:

"Dan tidaklah Aku menciptakan jin dan manusia, melainkan supaya mereka menyembah-Ku". (QS. Adz Dzariyat: 56).

"Maka apakah kamu mengira, bahwa sesungguhnya Kami menciptakan kamu secara main-main (saja), dan bahwa kamu tidak akan dikembalikan kepada Kami?" (QS. Al Mukminun: 115)

Sebagai bagian dari fungsi manajemen, Public Relations dalam organisasi adalah sebuah tim yang harus harus bekerjasama, solid dan bertekad 
dengan satu tujuan sesuai tujuan organisasi. Dalam hidup bermasyarakat Allah SWT sudah menetapkan bagaimana manusia hidup hendaknya berjamaah dan hidup saling tolong menolong. Seperti firma Allah:

Dan tolong-menolonglah kamu dalam (mengerjakan) kebajikan dan taqwa, dan jangan tolong-menolong dalam berbuat dosa dan pelanggaran. Dan bertaqwalah kamu kepada Allah, Sesungguhnya Allah amat berat siksaNya. (QS Almaidah : 2).

Adapun prinsip kerja dalam Islam adalah basis sebagai sumber etika kerja semua profesi. Contohnya adalah dalam kedisiplinan mengelola waktu.

"Dan (ingatlah) akan hari (yang waktu itu) Allah mengumpulkan mereka (mereka merasa di hari itu) seakanakan mereka tidak pernah tinggal (di dunia) melainkan sesaat saja di siang hari (yang waktu itu) mereka saling berkenalan" (QS Yunus: 45).

Ataupun dalam niat mencari rezeki berpegang pada firman Allah SWT:

"dan carilah pada apa yang telah dianugerahkan Allah kepadamu (kebahagiaan) negeri akhirat, dan janganlah kamu melupakan bahagianmu dari (kenikmatan) duniawi dan berbuat baiklah (kepada orang lain) sebagaimana Allah telah berbuat baik, kepadamu, dan janganlah kamu berbuat kerusakan di (muka) bumi. Sesungguhnya Allah tidak menyukai orang-orang yang berbuat kerusakan." (Q.S Al Qasas: 77).

Public Relations dalam tugasnya membangun hubungan yang saling menguntungkan ini perlu menciptakan hubungan yang positif dengan cara-cara yang positif pula. Oleh karenannya seorang Praktisi Public relations perlu memahami konten dan perilaku komunikasi. Komunikasi menjadi penting karena ketidak harmonisan hubungan antara manusia dalam organisasi ataupun dalam kehidupan dimasyarakat karena salah persepsi, miskomunikasi atau salah paham.

Islam menekankan kepada seluruh umat manusia agar berkomunikasi melalui perkataan yang mulia:

“... janganlah kamu mengatakan 'ah' kepada mereka (orang tua), jangan pula kamu membentak mereka dan ucapkanlah kepada mereka perkataan yang mulia!" (QS al-Isra`: 23).

Dan berkata-kata dengan baik.

"Dan janganlah kamu menyerahkan harta (mereka yang ada dalam kekuasaanmu) kepada orang-orang yang belum sempurna akalnya (anak yatim) yang dijadikan Allah sebagai pokok kehidupan!berilah mereka belanja dan pakaian (dari hasil harta itu) dan ucapkanlah kepada mereka kata-kata yang baik!" (QS an-Nisa: 5).

Nabi Muhammad Shallalahu

Alaihi wa Sallam memberi tauladan kepada umatnya agar dalam praktek bermasyarakat manusia senantiasa bersikap dan berperangai lembah lembut kepada saudara sesama muslim atau pun dengan saudara yang tidak muslim. Pada awal masa kenabian Rasulullah Muhammad Shallallahu Alaihi wa Sallam berdakwah dengan cara syiri atau sembunyi sembunyi. Orang yang pertama kali mendapat hidayah dakwah adalah istri, kerabat, sahabat dan saudara. Mereka adalah orang paling dekat, public internal yang menjadi sasaran utama tonggak perjuangan dakwah.

Selanjutnya dalam istilah public relations juga dikenal dengan istilah public internal dan public eksternal. Public internal adalah public yang ada di dalam internal perusahaan. Contoh public internal adalah pemegang saham, manajemen, karyawan, dan keluarga karyawan. Sedangkan public eksternal adalah public yang ada dalam lingkungan eksternal perusahaan dan 
ikut terimbas terhadap maju mundurnya sebuah organisasi. Contoh public eksternal adalah masyarakat, pemerintah, bank, NGO dan lain-lain.

Kekuatan internal dalam membangun organisasi menjadi penting karena dengan kekuatan organisasi dan sumber daya insani yang kuat akan menguatkan juga reputasi organisasi. Sehingga citra organisasi yang muncul di masyarakat adalah alamiah, tidak mengada-ada, tidak dimanipulasi, jujur, tidak berbohong. Maraknya profesionalisme praktisi Public Relations di masyarakat saat ini tidak dipungkiri mendorong munculnya citra palsu. Karena reputasi organisasi atau reputasi individu yang tidak positif dibangun dengan citra yang positif. Akhirnya umat yang ditipu dan menimbulkan kerugian.

Demikian juga dalam fase Rasulullah Shallallahu Alaihi wa Sallam memulai dakwah terangterangan. Orang-orang terdekatlah yang paling pertama dikunjungi oleh beliau. Maksudnya dari kalangan orang terdekat ini yang akan menjadi pondasi kekuatan dakwah. Di fase ini ladang dakwah sudah mulai meluas lagi tidak hanya pada keluarga inti tetapi kalangan bani Hasyim. Metode yang Rasulullah pakai adalah dengan mengundang untuk bersilaturahim. Adanya undangan, cara mengundang, tabligh adalah benihbenih publisitas sebagai bagian khusus yang tidak terpisahkan dari kegiatan public relations.

Dalam melaksanakan dakwah ini baik itu dakwah syiri ataupun jahr, atau sembunyi-sembunyi dan terangterangan Rasulullah tetap berprinsip pada firman Allah untuk mengajak umat menyembah Allah SWT dan tidak menyekutukannya.Walau pada prakteknya prinsip ini mendapat tentangan hebat dari lingkungannya. Meskipun sikap masyarakat menentang dan tidak sepakat, maka prinsip kebenaran harus tetap ditegakkan.

Dalam tugas ini mulai terasa ada perbedaan kepemimpinan Rasul dan praktek kinerja public relations saat ini. Praktisi public relations bekerja membangun citra publik yang positif. Landasannya adalah reputasi yang baik. Untuk itu public relations perlu menjalin komunikasi dan berhubungan timbal balik. Apa yang diingini publik itulah kepentingan publik. Bagaimana praktisi harus cerdas mengelola opini dan sikap public. Citra harus dibangun dari reputasi yang jujur.

Adapun yang dikerjakan Rasul utamanya, berdasar dengan membangun reputasi, membangun akidah yang kuat adalah permasalahan urgen yang harus diselesaikan ditingkat dasar. Apa yang harusnya disampaikan secara jujur, harus disampaikan secara tegas. Dalam memutuskan suatu kebenaran Rasulullah tidak mengenal kompromi.

Al Quran adalah sumber etika tertinggi dalam Islam, sebab Al Quran berisi firman-firman Allah SWT.Al Quran bersifat Syamil, muttakamil, sempurna dan lengkap.Segala sesuatu yang menyangkut perkara dunia dan akhirat tercantum dalam isi Al Quran. Public relations dalam mengemban kinerjanya baik oleh lembaga maupun praktisi bersumber pada kode etik profesi yang dikeluarkan oleh IPRA (International Public Relations Assosiation) dan Perhumas untuk cakupan wilayah di Indonesia.

Allah Berfirman :“...Barangsiapa tidak memutuskan perkara menurut apa yang diturunkan Allah, maka mereka itu adalah orang-orang yang fasik."(QS. Al-Maidah : 47).

Arthur W. Page menyebutkan sejumlah prinsip yang dapat digunakan dalam praktek dan sebagai filosofis PR dalam 
menjaga hubungan lembaga dengan publiknya.

1. Tell the Truth.

Biarkan publik tahu apa yang terjadi dan sediakan gambar yang akurat dari karakter ideal dan praktek lembaga. Berikan gambaran yang tepat, dan sediakan informasi yang dibutuhkan kepada publik. Dengan demikian, publik mengetahui apa yang terjadi, dengan sebenar-benarnya tanpa ada yang ditutupi. Kebutuhan mereka akan informasi yang benar terpenuhi, dan hubungan baik antara lembaga dengan publiknya dapat dijaga.

Dengan prinsip ini Arthur menyatakan bahwa biarkan publik tahu apa yang terjadi dan sediakan gambar yang akurat dari karakter ideal dan praktek lembaga. Berikan gambaran yang tepat, dan sediakan informasi yang dibutuhkan kepada publik. Dengan demikian, publik mengetahui apa yang terjadi, dengan sebenar-benarnya tanpa ada yang ditutupi. Kebutuhan mereka akan informasi yang benar terpenuhi, dan hubungan baik antara lembaga dengan publiknya dapat dijaga.

Dalam prinsip Islam ditekankan bagi umatnya untuk bertingkah laku sesuai prinsip kebenaran. Allah berfirman :"Hai orang-orang yang beriman bertakwalah kepada Allah, dan hendaklah kamu bersama orang-orang yang benar." (QS. At Taubah: 119).

Islam juga menekankan agar umatnya selalu memegang prinsip kejujuran. Allah berfirman. "Tetapi jikalau mereka berlaku jujur pada Allah, niscaya yang demikian itu lebih baik bagi mereka." (QS. Muhammad: 21).

Pesan Arthur mengingatkan umat Islam bahwa sejatinya syariah Islam sudah mengatur prinsip-prinsip transparansi sejak agama ini ada dan umat Islam melaksanakan praktek ibadah dan muamallah. Karena syariat
Islam mengatur secara detail aturan atau fiqh menyangkut hal yang terlihat dan tidak terlihat. Contoh dalam pelaksanaan ibadah, umat Islam mau tidak mau harus paham aturan bersuci, mensucikan sesuatu yang terlihat seperti najis. Dan mensucikan sesuatu yang tidak terlihat misalnya hati dan pikiran yang kotor ataupun hadast seperti buang angin.

Al Quran juga mengatur sesuatu yang sangat detail seperti dalam kegiatan jual beli. Allah Berfirman :

"...padahal Allah telah menghalalkan jual beli dan mengharamkan riba..." (QS. AlBaqarah: 275). Firman ini ditekankan lagi oleh Allah SWT bahwa:

"dan segala hal yang kalian datangkan berupa riba agar dapat menambah banyak harta manusia, maka riba itu tidak menambah apapun di sisi Allah." (QS 30: 3).

Demikian juga dalam perhitungan Allah memerintahkan untuk jujur dan tidak curang, ukuran, takaran, timbangan dalam perkara jual beli hendaknya di beritahukan secara terang-terangan. Allah berfirman: "kecelakaan besarlah bagi orang-orang yang curang, yaitu orang-orang yang apabila menerima takaran dari orang lain mereka minta dipenuhi, dan apabila mereka menakar atau menimbang untuk orang lain, mereka mengurangi." (QS 83: 1-3).

Nyata dalam Islam seluruh perintah Allah SWT yang harus dilaksanakan hambanya bersifat terbuka. Setiap ada perintah Allah SWT, Allah SWT menurunkan sekaligus petunjuk pelaksanaan dan petunjuk teknisnya. Contohnya dalam perintah Shalat. Allah berfirman: "Padahal mereka tidak disuruh kecuali supaya menyembah Allah dengan memurnikan ketaatan kepada-Nya dalam (menjalankan) agama yang 
lurus, dan supaya mereka mendirikan shalat dan menunaikan zakat; dan yang demikian itulah agama yang lurus." (QS. Al Bayyinah: 5), .... dirikanlah shalat untuk mengingat-Ku. (QS. Thaahaa: 1). Maka dirikanlah shalat, sesungguhnya shalat itu adalah kewajiban yang telah ditentukan waktunya atas orang-orang yang beriman.(QS. An-Nisaa': 103).

Ayat-ayat tersebut didukung oleh Hadist Nabi tentang tata cara Shalat : Dari 'Abdullah bin 'Umar, ia berkata : Rasulullah SAW bersabda, "Islam itu terdiri atas lima rukun. Mengakui bahwa tidak ada Tuhan melainkan Allah, dan sesungguhnya Muhammat itu adalah utusan Allah, mendirikan shalat, menunaikan zakat, hajji ke Baitullah dan puasa Ramadlan (HR. Ahmad, Bukhari dan Muslim).

Dari Jabir, ia berkata : Rasulullah SAW bersabda, "(Yang membedakan) antara seseorang dan kekufuran adalah meninggalkan shalat”. (HR. Jama'ah, kecuali Bukhari dan Nasai).

2. Buktikan dengan Tindakan (Prove it with Action).

Persepsi publik dari lembaga ditentukan 90\% dengan 'melakukan,' dan $10 \%$ dengan 'bicara.' Setiap kegiatan maupun perilaku lembaga pemerintahan, selalu menjadi perhatian publik. Perilaku lembaga, menjadi sumber informasi bagi publik dalam memberikan penilaian akan kinerja lembaga. Perilaku tersebut dapat dinilai dari cara kerja anggota lembaga, arus informasi, dan segala peristiwa maupun kejadian yang terjadi di dalam lembaga. Persepsi publik dari lembaga ditentukan 90\% dengan 'melakukan,' dan 10\% dengan 'bicara.' Setiap kegiatan maupun perilaku lembaga pemerintahan, selalu menjadi perhatian publik. Perilaku lembaga, menjadi sumber informasi bagi publik dalam memberikan penilaian akan kinerja lembaga. Perilaku tersebut dapat dinilai dari cara kerja anggota lembaga, arus informasi, dan segala peristiwa maupun kejadian yang terjadi di dalam lembaga. Dalam prinsip syariah Islam tindakan merupakan cermin dari keimanan. Tidak ada seorang manusiapun yang tahu akan tingkat keimanan seseorang kecuali bila orang tersebut mengimplementasikannya dalam tindakan. Allah berfirman :

"Dan orang-orang yang beriman dan mengerjakan amalan-amalan yang shaleh" (QS. An Nisa': 57). Orang dapat dikatakan beriman atau tidak jika ia telah melakukan amalan-amalan sholeh. “...Barangsiapa taat kepada Allah dan Rasul-Nya, niscaya Allah memasukkannya kedalam surga yang mengalir didalamnya sungai-sungai, sedang mereka kekal di dalamnya; dan Itulah kemenangan yang besar." (QS. An-Nisaa: 13).

"Sesungguhnya telah ada pada diri Rasulullah itu suri tauladan yang baik bagi kamu, yaitu bagi orang-orang yang mengharapkan menemui Allah dan Hari Akhir dan mengingat Allah sebanyak-banyak" (QS Al Ahzab 33: 21).

Rasulullah Shallallahu Alaihi wa Sallam mendapat gelar khutwah dan uswah artinya adalah tauladan dan contoh yang baik. Nabi dalam metode dakwah selalu memberikan contohcontoh konkrit berupa tindakantindakan yang baik. Misalnya setiap pagi Rasulullah selalu memberi makan dan mengunyahkan pengemis wanita di pojok kota. Padahal pengemis wanita yang buta tersebut terus memakimakinya. Rasulullah memberi contoh dengan tidak membalas keburukan yang ditimpakan kepadanya dengan keburukan yang sama, tetapi beliau justru selalu mendoakannya.

Bagi beliau pemimpin umat hendaklah memberi contoh yang baik 
akan lebih berbekas di hati umatnya daripada hanya sekedar kata-kata. Rasulullah Shallallahu Alaihi wa Salam bersabda: "Berbaktilah kepada orang tua kalian, niscaya anak-anak kalian akan berbakti kepada kalian”. (HR Bukhari).

Rasulullah juga pernah bersabda: "barangsiapa yang memberikan contoh yang baik dalam Islam maka baginya pahala atas perbuatan baiknya dan pahala orang-orang yang mengikutinya hingga hari kiamat. Yang demikian itu tidak menghalangi pahala orang-orang yang mengikutinya sedikitpun.........." (HR Thabrani).

Islam secara jelas mengajarkan kepada umat agar memberi contoh yang baik, akhlaq yang mulia yang bisa dilihat dan dicontoh orang lain dibanding hanya menyeru saja.

3. Dengarkan Suara

Konsumen/Masyarakat ( Listen to The Customer)

Untuk kebaikan lembaga, mengertilah pada keinginan dan kebutuhan publik. Biarkan pembuat keputusan atas dan karyawan lainnya tetap diinformasikan tentang reaksi publik terhadap kebijakan, dan praktek lembaga.

Untuk kebaikan lembaga, mengertilah pada keinginan dan kebutuhan publik. Biarkan pembuat keputusan atas dan karyawan lainnya tetap diinformasikan tentang reaksi publik terhadap kebijakan, dan praktek lembaga.

Hukum Islam yang tegas dan figih yang kuat dipahami dan dilaksanakan umat Islam adalah keputusan Allah SWT dan keputusan Rasulullah Shallallahu Alaihi wa Sallam dengan kepekataan mempertimbangkan umat. Contoh perintah shalat yang diperintahkan Allah SWT kepada umat Islam. Awalnya perintah Shalat adalah 50 waktu tetapi Rasul Muhammad SAW terus memohon keringanan kepada Allah SWT dengan mengingat kemampuan umatnya.

Beberapa kejadian yang tercantum dalan shiroh nabawi juga menyiratkan bahwa nilai-nilai Islam selalu menetapkan hukum berdasarkan pertimbangan umat. Contoh ketika di bulan Ramadhan tepat di malam keempat Rasul Muhammad SAW mendirikan shalat tarawih di rumah, sementara tiga malam pertama Rasul melaksanakannya di masjid secara berjamaah. Para sahabat dan umat Islam yang lain sudah menunggu. Dan beliau memang sengaja shalat tarawih dirumah karena takut kalau-kalau ada ayat Allah SWT turun yang akan mewajibkan shalat tarawih. Salah satu pertimbangan adalah suara umatnya, kemampuan umatnya terutama dalam keimanannya. Rasulullah senantiasa memperhatikan umatnya.

Kisah ketika Nabi dan para sahabat sedang shalat dimasjid dan tibatiba ada orang Arab Badui yang kencing di dalam masjid. Para sahabat pada waktu itu marah dan ingin mencelakainya. Namun Rasul melarang dan menyuruh salah satu diantaranya membersihkan. Rasulullah Shallallahu Alaihi wa Sallam memaklumi karena orang Arab Badui tadi belum paham. Beliau selalu memahami kemampuan umatnya.

Islam telah mencontohkan bagaimana seorang pemimpin mendengar hati nurani anggotanya. Kinerja profesi public relations yang intinya adalah membangun dan menjaga hubungan baik, membangun sikap dan opini positif dengan kejujuran yang tidak dibuat-buat. Kinerja public relations saat ini masih menggunakan standar profesi Barat yang sumbernya adalah para ilmuwan Barat. Sedangkan ditinjau dari syariat Islam, menggunakan pemahaman dari $\mathrm{Al}$ 
Quran yang keseluruhannya adalah firman Allah SWT.

4. Siapkan Diri untuk Esok (Manage for Tomorrow)

Antisipasi reaksi publik dan hilangkan praktek yang menciptakan kesulitan. Ciptakan niat baik, setiap kegiatan yang dilakukan saat ini, akan berdampak di masa depan. Demikian juga di dalam lembaga. Penting bagi sebuah lembaga untuk merencanakan setiap kegiatan, program maupun aktifitas sehari-hari yang akan dilakukan dengan baik. Perencanaan untuk kegiatan di masa depan, bermanfaat dalam menghindarkan kesulitan-kesulitan maupun kekacauan yang mungkin terjadi di masa depan. Konsep manajemen Qur' ani menjelaskan bahwa setiap manusia (bukan hanya organisasi) hendaknya memperhatikan apa yang telah diperbuat pada masa yang telah lalu untuk merencanakan hari esok. Dalam Al Qur'an Allah berfirman :

" Hai orang-orang yang beriman, bertakwalah kepada Allah dan hendaklah setiap diri memperhatikan apa yang telah diperbuatnya untuk hari esok (akhirat), dan bertakwalah kepada Allah, sesungguhnya Allah Maha Mengetahui apa yang kamu kerjakan”. (Q.S. Al Hasyr : 18)

Hal menarik dari ayat tersebut adalah perintah kepada orang-orang yang beriman dimulai dengan bertakwa kepada Allah untuk selanjutnya mempersiapkan bekal untuk masa depannya baik di dunia maupun di akhirat kemudian ditutup dengan perintah takwa. Artinya kehidupan seorang muslim adalah kehidupan terencana, yang dipersiapkan dengan sebaik-baiknya untuk mendapatkan tujuan kebaikan di dunia dan di akhirat. Seorang muslim bukanlah layanglayang yang terbang sekehendak angin berlalu melainkan sosok pribadi yang tahu arah dan tujuan hidupnya. Seorang muslim harus memiliki manajemen ketakwaan karena sesungguhnya kebaikan tidak akan diperoleh tanpa upaya sungguh-sungguh.

Bagaimana caranya agar manajemen takwa ini dapat terwujud ? Imam $\mathrm{Al}$ Ghazali dalam kitab Tazkiyatun Nafs nya membagi tangga menuju takwa terdiri atas lima tingkatan dan dilakukan modifikasi dan kontekstualisasi yaitu :

1. Mu'ahadah (dedikasi) : perjanjian yaitu menguatkan kembali niat dan komitmen bahwa segala yang dikerjakan adalah semata-mata karena Allah sehingga tujuan demi kebaikan serta pelaksanaan juga akan sebaik-baiknya karena merupakan ibadah dan persembahan kepada Allah.

2. Muhasabah (evaluasi) : penghitungan yaitu evaluasi diri di awal pekerjaan berbasis data yang akurat dan objektif untuk mengetahui kekuatan, kelemahan, peluang dan tantangan sehingga menyusun target betul-betul realistis dan menantang dan dapat dicapai dengan penuh antusias. Evaluasi juga terus dilakukan saat pelaksanaan pekerjaan untuk menghadapi dan mengantisipasi segala kendala yang ada untuk selanjutnya disiasati dengan cerdas sehingga target tetap dapat tercapai.

3. Mujahadah (optimalisasi) : kesungguhan yaitu mengerjakan rencana dengan penuh kesungguhan melalui pengerahan secara optimal segala potensi yang dimiliki baik sumber daya manusia, material, mesin, metode dan dana. 
4. Muraqabah (kontrol) : pengawasan yaitu dalam melaksanakan pekerjaan diperlukan pengendalian untuk meluruskan yang tidak lurus, mengoreksi yang salah, dan membenarkan yang salah.

5. Mu'aqabah (konsekwensi) : yaitu penghargaan (reward) dan hukuman (punishment) yang berguna untuk memotivasi. Dalam Islam ada istilah basyir (berita gembira) dan nadzir (berita ancaman) yang dianalogikan dengan penghargaan dan hukuman. Kedua hal ini tidak boleh dipisahkan. Jika yang dilakukan hanya memberi reward saja, maka seseorang akan memiliki semangat untuk melakukan sesuatu karena tujuan jangka pendek. Jika yang dilakukan hanya hukuman saja, maka seseorang cenderung menjadi takut dan tidak berkembang. Lebih jauh lagi, Allah menyiapkan pahala dan dosa, surga dan neraka atas segala aktivitas dan amal manusia. Sehingga yang terbaik untuk ditumbuhkan dalam penghargaan yaitu harapan penghargaan dari Allah dan ketakutan hukuman dari Allah.

Ali bin Abi Thalib r.a. berkata : Semua orang merugi kecuali yang beriman. Semua orang beriman merugi kecuali yang berilmu. Semua orang berilmu merugi kecuali yang beramal.Semua orang beramal merugi kecuali yang ikhlas.

Dari keterangan ayat diatas kita sejenak berkontemplasi, bahwa Allah SWT memerintahkan untuk memberikan perhatian akan masa depan, walaupun secara tersurat ayat tersebut menyatakan untuk memperhatikan masa depan di akhirat. Akan tetapi secara tersirat kita bisa mengambil kesimpulan bahwa memeperhatikan masa depan di dunia juga penting disamping juga di akhirat. Sebagaimana dalam firman Allah yang lain: "Dan carilah apa yang telah diberikan oleh Allah kepadamu dari negeri akhirat, dan jangan lupakan bagianmu di dunia." (al-Qashash ayat 77).

5. Lakukan Tindakan PR Seakan Seluruh Lembaga/Lembaga Bergantung Padanya (Conduct Public Relationss as If The Whole Company Depends On it)

PR lembaga adalah fungsi manajemen. Tidak ada strategi lembaga yang dapat diimplementasikan tanpa memikirkan dampaknya kepada publik. Profesional PR adalah pembuat kebijakan yang mampu menangani aktifitas komunikasi lembaga dengan jangkauan yang luas. Salah satu bentuk perjuangan adalah dengan bekerja, bekerja keras juga cerdas. Tak kalah penting bekerja dengan hati! Hati-hati jadi korupsi. Korupsi itu hal kecil yang terakumulasi menjadi sebuah kejahatan besar! Penjahat manusia yang harus musnah jika ingin aman sentosa kita punya negara! Aha, balik lagi pada soal bekerja! Tulus bekerja karena Allah Rabbul'izzati membuat kita lebih berarti "Sebaik-baiknya usaha adalah usaha tangan seorang pekerja apabila ia mengerjakan dengan tulus". (Ahmad). Ikhlas harus turut serta menjadi bagian terpenting begitu pula kejujuran. Banyak orang yang pintar sekarang ini, tapi mengenaskan di sisi lain semakin langkah orang jujur!. Berjuang sepenuh hati! Bila hanya setengah hati atau bahkan seperempat asa maka kita akan begitu dekat dengan kegagalan karena kegagalan adalah milik mereka yang melangkahkan setengah hati, tak jelas apa yang dicari (From zero to hero). 
Lagi pula apa nikmatnya bekerja setengah-setengah, asal-asalan, asal jadi, asal kerja bukankah hasilnya pun tak maksimal. Bukankah Allah mewajibkan kita bekerja profesional "Sesungguhnya Allah mewajibkan kebaikan (Profesionalitas) atas segala sesuatu” (HR.Muslim).

Mungkin perintah ini belum lah cukup untuk membuat kita tersadar dan bangun dari kemalasan bekerja tanpa semangat, maka coba renungkan! Paling tidak baca dengan hati, "Dan Katakanlah: Bekerjalah kamu, maka Allah dan Rasul-Nya serta orang-orang mukmin akan melihat pekerjaanmu itu, dan kamu akan dikembalikan kepada (Allah) yang Mengetahui akan yang ghaib dan yang nyata, lalu diberitakanNya kepada kamu apa yang telah kamu kerjakan.” (Q.S. At-taubah: 105). Sekali lagi ingat akhirat bila ingin selamat! Saat di Padang Mahsyar nanti, kita akan dipertontonkan semua adeganadegan yang pernah kita lakoni di dunia ini. Semua perbuatan-perbuatan yang sudah kita perbuat tak kan luput bahkan kejahatan sekecil biji kurma.

Allah adalah Tuhan yang bergantung kepada-Nya segala sesuatu (QS. Al Ikhlas [112] : 2). Salah satu nama Allah dalam Asma'ul Husna adalah Ash Shamad. Kata ini ada dalam Al Quran surah Al-Ikhlas, dan memang kata Ash Shamad hanya disebut satu kali dalam Alquran.Ash Shamad dapat diartikan sebagai Allah Yang Maha Dibutuhkan.

Allah adalah tempat bergantung segala sesuatu, maka kita harus bergantung sepenuhnya hanya pada Allah. Dan apabila kita telah benar-benar hanya bergantung kepada Allah, maka berarti kita tidak akan pernah meminta sedikit pun kepada selain Allah. Karena hanya Allah yang Maha Mengetahui semua kebutuhan kita.Dan yang sesungguhnya adalah, tidak ada siapapun dan apapun yang bisa menolong kita, selain Allah dan atas ijin Allah. Dalam kehidupan kita di dunia, khususnya dalam memenuhi apa yang menjadi hajat kebutuhan hidup kita, masih ada dari kita yang kadang bergantung dan berharap pada mahluk, karena itu sebagian dari kita sering berusaha sekuat tenaga untuk mendapat simpati dari mahluk. Ini adalah kekeliruan yang sangat besar, karena menggantungkan harapan pada makhluk hanya akan menimbulkan kekecewaan saja.

Karena pada dasarnya, mahluk yang kita jadikan tumpuan harapan, sebenarnya tidak punya kuasa apapun untuk dapat memenuhi harapan kita, tanpa ijin dari Allah. Karena hanya Allah lah yang bisa membuat segalanya terjadi.Allah jugalah yang mengatur skenario dibalik segala peristiwa.Tidak ada satupun yang terjadi di dunia ini, yang lepas dari pengawasan dan pemantauan-Nya. Jadi seharusnya kita hanya menggantungkan segala harapan hanya kepada Allah SWT, yang mana jiwa kita ini ada dalam genggamannyaNya.

Jangan pernah berharap dan atau meminta pertolongan kepada mahluk, seberapa hebat pun ia dimata kita. Karena, sehebat apapun, yang namanya mahluk, tidak akan pernah dapat memberikan pertolongan apapun kepada kita tanpa ijin Allah. Dan pada dasarnya, semua mahluk sama dengan kita, yaitu selalu berhajat memohon bantuan pertolongan kepada Allah. Ketahuilah, makhluk itu sangat lemah dan tidak memiliki daya serta kekuatan apapun selain dari yang diberikan oleh Allah.

Karena itu, jika kita hendak meminta pertolongan dan perlindungan, maka mintalah pertolongan dan perlindungan hanya kepada Allah, Yang Maha Kuat, Maha Perkasa, Maha Kokoh dan Maha Melindungi. Karena 
itu, kita harus melatih diri untuk tidak bergantung pada makhluk, termasuk pada jabatan, harta, pasangan hidup, dan pertolongan manusia atau mahluk.

Perhatikan doa Rasulullah SAW berikut ini: seperti yang disampaikan oleh Abdullah bin Umar ra. Ia mengatakan bahwa Rasulullah SAW tidak pernah meninggalkan untaian doa ini ketika pagi dan sore: "Ya Allah, aku memohon kepada-Mu keselamatan di dunia dan akhirat. Ya Allah aku memohon kepada$M u$ ampunan dan keselamatan dalam agamaku, duniaku, keluargaku dan hartaku.Ya Allah, tutuplah auratku. Lindungilah ketakutanku. Ya Allah peliharalah aku dari hadapanku, dari belakangku, dari sisi kananku, dari sisi kiriku, dari atasku. Aku berlindung dengan keagunganMu diserang dari bawahku." (HR. Abu Daud dan Ibnu Majah).

Seperti itulah permohonan yang dipanjatkan Rasulullah SAW.Mohon agar perlindungan dari Allah SAW selalu menyertainya dari semua sudut, dari semua sisi, tanpa celah dan lubang yang tersisa dan disetiap waktu. Meminta agar Allah SWT tak pernah membiarkannya menjadi incaran dan korban semua kejahatan dari makhlukmakhluk-Nya.Sungguh-sungguh memanjatkan harapan agar Allah SWT menyelamatkan agama, dunia dan akhiratnya, menutupi kekurangannya, membentengi ketakutannya.

Perhatikan juga doa yang diucapkan Amirul Mukminin, Umar bin Khattab ra. Yang meminta perlindungan kepada Allah SWT dari segala sisi.Memohon semua kebaikan dan menolak semua kejahatan.

"Ya Allah, peliharalah aku dengan Islam ketika aku berdiri.Peliharalah aku dengan Islam ketika aku duduk.Peliharalah aku dengan Islam ketika aku terbaring.Jangan gembirakan orang yang memusuhiku dan yang menyimpan dengki kepadaku.Ya Allah, aku memohon kepada-Mu semua simpanan kebaikan yang ada di Tangan-Mu.Dan aku berlindung kepada-Mu dari seluruh simpanan kejahatan yang ada di Tangan-Mu." (HR. Al Hakim dalam Al Mustadrak, I/525)

Hasbunallahu wa ni'mal wakiil, ni'mal maulaa wa ni'man nashiir. Cukuplah Allah menjadi penolong kami dan Allah adalah sebaik-baik pelindung. Dia adalah sebaik-baik pelindung dan sebaik-baik penolong. Pengharapan total pada Allah adalah amalan batin. Kita harus proporsional dalam bertindak, jangan sampai kita salah mengartikan "bergantung sepenuhnya kepada Allah" menyebabkan kewajiban kita sebagai manusia, yaitu beikhtiar dan berusaha tidak kita jalankan. Perhatikan firman Allah SWT berikut ini: "Sesungguhnya Allah tidak mengubah keadaan sesuatu kaum sehingga mereka mengubah keadaan yang ada pada diri mereka sendiri." (QS ar-Ra'du [13] : 11).

Jadi jangan salah persepsi, karena bergantung pada Allah, bukan berarti meniadakan usaha dan ikhtiar untuk mencari penghidupan.Kita harus tetap berusaha dan beikhtiar mencari penghidupan.Namun dalam mencarinya kita tidak boleh bergantung dan bersandar pada mahluk dan atau pada usaha yang kita lakukan.Kita harus tetap sepenuh hati menggantungkan segala hasil usaha atau ikhtiar yang kita lakukan pada Allah Yang Maha Menentukan.

Bila bila kita telah benar-benar hanya bergantung kepada Allah. Kita akan menyadari, bahwa Allah SWT lah Yang Lebih Berkuasa dari segala mahluk yang berkuasa. Kekuasaan Allah meliputi kekuasaan orang-orang yang berkuasa. Allah lah yang menggenggam jiwa orang-orang yang 
berkuasa. Allah Lah yang menggenggam dunia dan akhirat. Jadi bila kita telah menyadari dan menerapkan keyakinan itu dalam hidup kita, percayalah, Allah SWT akan memberikan pertolongan dan perlindungan pada kita. Kekuatan Allah lah yang akan menolong kita, karena Allah Maha Mengetahui, Maha Kuasa atas segala sesuatu. Hidup kita, pekerjaan kita, lingkungan di sekitar kita, semua berada dalam pantauan Allah.

\section{Remain Calm, Patient and Good} Humored

Bersandarlah pada sikap yang konsisten, tenang dan berdasarkan perhatian ketika menyampaikan informasi, atau melakukan kontak. Bila krisis muncul, ingat bahwa komunikasi dengan kepala dingin adalah yang terbaik.

Kegiatan komunikasi pada dasarnya adalah kegiatan yang sifatnya persuasif. Lembaga berusaha untuk mendapatkan dukungan melalui kegiatan-kegiatan yang dapat memancing dukungan dari publik tanpa paksaan atau melalui sebuah tahapan konflik.Arthur W. Page menyebutkan sejumlah prinsip yang dapat digunakan dalam praktek dan sebagai filosofis PR dalam menjaga hubungan lembaga dengan publiknya. Prinsip tersebut meliputi: Tell the Truth, Prove it with Action, Listen to The Customer, Manage for Tomorrow, Conduct Public Relationss as If The Whole Company Depends On it, Remain Calm, Patient and Good Humored. Prinsip-prinsip kinerja tersebut dibuat dalam sudut pandang ilmuan barat dan bukan tradisi keilmuan Islam. Karena itu pada penelitian ini akan dilihat bagaimana konstruksi syariat Islam dalam memandang prinsip-prinsip kinerja public relations tersebut. Hal ini penting mengingat praktek publc relations telah menjadi bagian tidak terpisahkan dari instansi, perusahaan maupun individu umat Islam.

Sabar adalah pilar kebahagiaan seorang hamba. Dengan kesabaran itulah seorang hamba akan terjaga dari kemaksiatan, konsisten menjalankan ketaatan, dan tabah dalam menghadapi berbagai macam cobaan. Ibnul Qayyim rahimahullah mengatakan, "Kedudukan sabar dalam iman laksana kepala bagi seluruh tubuh. Apabila kepala sudah terpotong maka tidak ada lagi kehidupan di dalam tubuh." (Al Fawa'id, hal. 95). Syaikh Muhammad bin Shalih Al 'Utsaimin rahimahullah berkata, "Sabar adalah meneguhkan diri dalam menjalankan ketaatan kepada Allah, menahannya dari perbuatan maksiat kepada Allah, serta menjaganya dari perasaan dan sikap marah dalam menghadapi takdir Allah...." (Syarh Tsalatsatul Ushul, hal. 24).

Syaikh Muhammad bin Shalih Al

'Utsaimin rahimahullah berkata, "Sabar itu terbagi menjadi tiga macam:

1. Bersabar dalam menjalankan ketaatan kepada Allah

2. Bersabar untuk tidak melakukan hal-hal yang diharamkan Allah

3. Bersabar dalam menghadapi takdir-takdir Allah yang dialaminya, berupa berbagai hal yang menyakitkan dan gangguan yang timbul di luar kekuasaan manusia ataupun yang berasal dari orang lain".

\section{Kesimpulan}

1. Dalam Islam Allah menyuruh manusia untuk bergabung dalam organisasi dan bekerjasama dengan manusia lain. Allah berfirman :"Sesungguhnya Allah menyukai orang-orang yang berperang (berjuang) dijalannya dengan terorganisasi rapih, 
seperti sebuah bangunan yang tersusun kuat". (QS. as-Shaf : 4).

2. Sebagai bagian dari fungsi manajemen, public relations dalam organisasi adalah sebuah tim yang harus harus bekerjasama, solid dan bertekad dengan satu tujuan sesuai tujuan organisasi. Dalam hidup bermasyarakat Allah SWT sudah menetapkan bagaimana manusia hidup hendaknya berjamaah dan hidup saling tolong menolong.

3. Public Relations dalam tugasnya membangun hubungan yang saling menguntungkan ini perlu menciptakan hubungan yang positif dengan cara-cara yang positif pula. Oleh komunikasi. Komunikasi menjadi penting karena ketidak harmonisan hubungan antara manusia dalam organisasi ataupun dalam kehidupan dimasyarakat karena salah persepsi, miskomunikasi atau salah paham.

4. Kegiatan komunikasi pada dasarnya adalah kegiatan yang sifatnya persuasif. Lembaga berusaha untuk mendapatkan dukungan melalui kegiatankegiatan yang dapat memancing dukungan dari publik tanpa paksaan atau melalui sebuah tahapan konflik. Arthur W. Page menyebutkan sejumlah prinsip yang dapat digunakan dalam praktek dan sebagai filosofis PR dalam menjaga hubungan lembaga dengan publiknya.

\section{Daftar pustaka}

Al Utsaimin, Muhammad bin Sholih. (2006). Ulasan Tuntas Tentang Tiga Prinsip Pokok. Jakarta: Darul Haq.
Moleong, Lexy. (2008). Metode Penelitian Kualitatif. Bandung: Remaja Rosda Karya.

Sihombing, Emrus. (2012). Membangun Teori Komunikasi Berbasis Riset Komunikasi Ke-Indonesia-An, dalam Prosiding Konferensi Nasional Ilmu Komunikasi. Jakarta: UPH Press.

Utari, Prahastiwi. (2012). Make A Dream Comes True, Membumikan Teori Komunikasi Indonesia, dalam Prosiding Konferensi Nasional Ilmu Komunikasi. Jakarta: UPH Press.

Al-Qur'an.

http://www.kompasiana.com/shokhibul aarifin/merencanakan-masadepan_55184bf2a333114607b665 00.

muslim.or.id 